This is the version of the article accepted for publication in Modern Asian Studies published by Cambridge University Press: https://www.cambridge.org/core/journals/modern-asian-studies/all-issues

Accepted version downloaded from SOAS Research Online for private research and study only:

http://eprints.soas.ac.uk/23095/

\title{
Across the divide: Looking for the common ground of Hindustani* Across the divide
}

\author{
David Lunn \\ SOAS University of London \\ d124@soas.ac.uk
}

\begin{abstract}
This article investigates some of the institutional and poetic practices around the idea of Hindustani in the period 1900-47. It charts the establishment of the Hindustani Academy in 1927, and explores some of its publishing activities as it attempted to make a positive institutional intervention in the Hindi-Urdu debate and cultural field more broadly. It then considers some aspects of poetic production in literary journals, including those associated with the Academy. Ultimately, it is an attempt to explore the grey areas that existed between Hindi/Hindu and Urdu/Muslim in the pre-Independence decades, and to make the case for studying the literature of both traditions simultaneously, along with emphasizing that attempts at compromise — including the perennially contested term 'Hindustani' itself — must be taken on their own terms.
\end{abstract}

Sometime in the early 1940s, the prominent Urdu writer Saadat Hasan Manto weighed in on the Hindi-Urdu controversy with his trademark irony and wit. He prefaced his short story cum essay 'Hindī aur Urdū' ('Hindi and Urdu') with a note of bewilderment: prominent figures in literature and politics such as M.K. Gandhi, Tara Chand, and Abdul Haq may have understood the controversy, but not Manto: to him, the communal supporters of one language or the other were inexplicably wasting their time, and he could produce only the following fictional conversation as his own attempt to address the issue. This takes place between two characters - Munshi Narain Prashad and Mirza Muhammad Iqbal — who discuss the relative merits not of Hindi and Urdu per se, but of lemon and soda:

Munśī: Dekhie is kā faiṣlah yūin ho saktā hai ki leman aur soḍa donon miks kar le jāen்.

Iqbāl: Mujhe kō̄ e 'tirāz nahìn.

Munśi: To is khālī glās meñ àdhā soḍa dạl dījie.

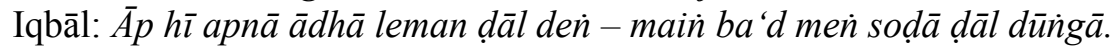

Munśi: Yeh to koì bāt na hotī. Pahle āp soḍa kyon nahìn ḍalte.

Iqbāl: Main soụa leman miksẹ pīnā cāhtā hün.

Munśî: Aur main leman sợa miksẹ pinnà cāhtā hǜn.

Munshi: Look, we can settle the matter by mixing the two.

Iqbal: I have no objection to that.

Munshi: Well then, fill this glass halfway with soda.

Iqbal: Why don't you fill half the glass with your lemon? I'll pour my soda after that.

Munshi: Makes no sense. Why don't you pour your soda first?

Iqbal: Because I want to drink soda-lemon mixed.

Munshi: And I want lemon-soda mixed. ${ }^{1}$

\footnotetext{
* I would like to thank Francesca Orsini for her generous advice and support throughout. Shabnum Tejani and Amina Yaqin also made very helpful interventions in earlier drafts of this work, and Geeta Patel was generous in discussing Miraji. I thank too audiences at SOAS University of London, and the University of Chicago, who heard earlier versions and offered many helpful comments. Librarians and archivists in the Hindustani Academy, Allahabad, the Hindi Sahitya Sammelan, Allahabad, and the British Library, London, have my deepest gratitude for their assistance and generosity. The research for this article was conducted as part of a $\mathrm{PhD}$ at SOAS University of London which was funded by the Arts and Humanities Research Council.
} 
This is the version of the article accepted for publication in Modern Asian Studies published by Cambridge University Press: https://www.cambridge.org/core/journals/modern-asian-studies/all-issues

Accepted version downloaded from SOAS Research Online for private research and study only:

http://eprints.soas.ac.uk/23095/

Manto's allegory is at once seemingly straightforward, yet also deeply nuanced. Neither denies that the other's preferred drink might have some merit, but equally neither is willing to adopt the drink of the other. Neither is able to give conclusive reasons why their preferred drink is superior, instead relying on spurious claims regarding the relative health benefits. And instead of articulating their own opinions on lemon or soda respectively, both simply state that they're following their elders' injunctions. For a moment it seems that a mixture of lemon and soda might provide a solution, yet even this attempt fails on the grounds of order, primacy, and nomenclature. So ends their attempt at compromise or coexistence - in failure, stalemate, and, apparently from Manto's perspective, frustrating banality.

Manto's piece highlights many of the issues most pertinent to the Hindi-Urdu controversy. The space between the preamble and the text itself symbolises the slippage between the domain of high nationalist politics - that occupied by the likes of Gandhi, Haq, and Tara Chand - and the lived, day-to-day reality of the language issue as experienced by ordinary and creative users. Manto's self-confessed inability to understand the issue, while a rhetorical device, suggests a dissonance between discussions of the language issue at the political level and the more grounded domain of literary endeavour and creation. The characters are probably references to the then recently deceased Urdu and Persian poet Muhammad Iqbal and Hindi author Jayshankar Prasad, litterateurs who had strongly advocated Persianised Urdu and Sanskritized Hindi respectively-Manto thereby highlights the complicity of sections of the literati in this affair. ${ }^{2}$ The steadfast allegiance of each character to his preferred drink indexes the then prevalent, though not exclusive, communal affiliations with language-Hindi with Hindu, Urdu with Muslim. Meanwhile, the justification that they preferred one drink to the other because they had been told by their elders of its superiority reminds us of the importance of inherited tastes, and prejudices, in the context of rapidly shifting linguistic structures and political imperatives.

The history of Hindi and Urdu, particularly the process of their differentiation both as languages and also as signifiers of religious and communal affiliations in the course of nineteenth- and early twentieth-century north India, has been examined at some length. ${ }^{3}$ Though the process was far from complete, by the end of the nineteenth century, Hindi and Urdu had become associated to a significant extent in public discourse with discrete religious communities. By the time that this article takes as it starting point (circa 1900), it was largely the norm to speak of Hindi and Urdu as two distinct languages, and it was in the 1920 s that what had been a largely provincial internecine contest between the partisans

\footnotetext{
${ }^{1}$ Saadat Hasan Manto, 'Hindī aur Urdū', Manțo ke mazāmīn, Delhi, Saqi Book Depot, 1997 [1942], pp, 71-5, 75, tr. Muhammad Umar Memon, 'Hindi and Urdu', Annual of Urdu Studies 25, 2010, pp. 205-8, pp. 207-8.

${ }^{2}$ Christine Everaert makes the same suggestion in her brief discussion of the story: 'One could wonder whether the names Iqbāl and Praśād are consciously chosen as a hint at the authors Muhammad Iqbāl (18771938) and Jayśaṇkar Prasād (1889-1937), who can be seen as promotors of Persianised and Islamised Urdu and Sanskritized Hindi respectively.' Christine Everaert, Tracing the boundaries between Hindi and Urdu: Lost and added in translation between $20^{\text {th }}$ century short stories, Leiden, Brill, 2010, p. 67.

${ }^{3}$ The classic account is Amrit Rai, A house divided: The origin and development of Hindi/Hindavi, Delhi, OUP, 1984. For study of the politics of this division see Christopher King, One language, two scripts: The Hindi movement in nineteenth century north India, Oxford, OUP, 1994. See also: Vasudha Dalmia, The nationalization of Hindu traditions: Bhāratendu Hariśchandra and nineteenth-century Banaras, New Delhi, OUP, 1997; Francesca Orsini, The Hindi public sphere, 1920-1940: Language and literature in the age of nationalism, Oxford, OUP, 2002; Alok Rai, Hindi nationalism, New Delhi, Orient Longman, 2001; Shamsur Rahman Faruqi, Early Urdu literary culture and history, New Delhi, OUP, 2001; and Tariq Rahman, From Hindi to Urdu: A social and political history, New Delhi, Orient Blackswan, 2011.
} 
This is the version of the article accepted for publication in Modern Asian Studies published by Cambridge University Press: https://www.cambridge.org/core/journals/modern-asian-studies/all-issues

Accepted version downloaded from SOAS Research Online for private research and study only:

http://eprints.soas.ac.uk/23095/

of Hindi and Urdu, played out in the United Provinces, became a national concern. So discourses of commonality were being articulated in the face of powerful political, communal (i.e. sectarian) and nationalist imperatives, many of which had subsumed language as a marker under a broader sectional identity.

Yet the evidence that significant 'grey areas' existed between the poles of Hindi/Hindu and Urdu/Muslim during this period is undeniable, whether in the form of the discourse of Hindustani as the language of the people, the creation of mixed registers of literary language in prose and poetry, the invocation of a common literary heritage, the continued use of Urdu by Hindus, the incorporation of Urdu forms into Hindi commercial genres, or the decided malleability and instability of both register and genre in the face of the new media of film. ${ }^{4}$ All these discourses and practices were manifest not only in the world of print journals, but also in the realms of literary and cultural production more generally, as well as in the building of institutions linked to literary and linguistic activities. Despite the unmistakeable divergence between high register/Sanskritized Hindi and Perso-Arabicized Urdu, I argue, there was a significant amount of overlap, and indeed interaction and mutual awareness, between the realms and practitioners of Hindi and Urdu, all of which is best considered in the context of a north Indian field of cultural production. I also suggest that it was these grey areas that constituted a forum for the working out of a mode of cultural and societal coexistence that has been largely overlooked in literary, linguistic and intellectual histories of the period.

This article explores the literary, cultural, and linguistic common ground between Hindi and Urdu during the nationalist period, and analyses the attempts by members of the cultural establishment to find, or create, the same. It briefly examines spaces, practices, and discourses of commonality in two largely distinct institutional and generic forms: literary institutions and poetry. While these areas do not encompass the entirety of cultural production in Hindi and Urdu, they are among the most significant for understanding the range of contexts and forms in which efforts to create, recover, or simply assert commonality took place. Pierre Bourdieu's understanding of the field of cultural production - spread over diverse sites, competitive, and with authority unevenly sought and exercised-best encompasses the interrelatedness and competitiveness of the fields of Hindi and Urdu during the colonial period: the attempted institutionalisation of linguistic and literary unity; the continued interaction between their journalistic spheres; the mutuality of forms and genres, and efforts made towards ensuring and facilitating exchange; the simultaneous participation of a variety of actors in the literary realms of both languages; the shared concerns of members of the literati working in both languages and their responses to such concerns; and the encompassing embrace of the traditions, forms and practitioners of both languages within the new filmic context. The field of Hindi/Urdu/Hindustani in the 1920 s and 30s was a field of possibilities, of entrenched positions and habitus, and of dynamic actors encountering an ever-changing political reality.

\section{Whose Hindustani?}

Hindustani was and remains a contested term: is it a point on a spectrum stretching from Sanskritized Hindi to Persianized/Arabicized Urdu?; if so, is it a simple, every-day language that necessarily lacks style, beauty, or the capacity for complex concepts? Or is it

\footnotetext{
${ }^{4}$ For a discussion of the latter process, see David Lunn, 'The Eloquent Language: Hindustani in 1940s Indian Cinema', Bioscope 6, 1, 2015, pp. 1-26.
} 
This is the version of the article accepted for publication in Modern Asian Studies published by Cambridge University Press: https://www.cambridge.org/core/journals/modern-asian-studies/all-issues

Accepted version downloaded from SOAS Research Online for private research and study only:

http://eprints.soas.ac.uk/23095/

a broadly conceived realm of inclusivity, in which any vocabulary and idiom is welcome?; if so, is it not impossibly broad? Or...the term was ripe for debate.

The various definitions were contested throughout the period, and indeed well before hand - much has been written on the colonial state's misadventures and misunderstandings in the Hindi-Urdu-Hindustani sphere. ${ }^{5}$ Gandhi forced the Hindī Sāhitya Sammelan to adopt his position of 'Hindi-Hindustani' in 1935-a definition based on a shared, spoken language, and one which ignored or sought to transcend the divide of script. ${ }^{6}$ As David Lelyveld has argued, the search for an inclusive definition for Hindustani was one that occupied Gandhi throughout the period from 1916 until Partition, ${ }^{7}$ and his ultimate failure to effect reconciliation is an enduring testament to the power and persistence of this issue. Gandhi's own vagueness seemed only to exacerbate the issue. As Alok Rai has pithily observed:

Gandhi's compromise formulation "Hindi or Hindustani" was doomed to failure. That "or" could denote either alterity or identity. It could mean either that Hindi was the same as Hindustani, so the mullah was up in arms, or that Hindustani was an alternative to Hindi, so the pandit, quite as pugnacious, would have none of it. ${ }^{8}$

Gandhi's two-script solution was a compromise too vague proposed at a point too late for it to have any traction in the political realm, serving only to incense the partisans of both Hindi and Urdu in equal measure. His romanticisation of the Indian village, and of the imagined linguistic harmony to be found in the speech of villagers, was ultimately powerless in the face of entrenched elite interests and oppositional nationalisms. Yet this idea of simplicity - in shared registers of communication, day-to-day speech, village life, the common man, and in simple religion-was a powerful motif. This idea was employed to great effect by Hindi and Urdu short story writers in particular, and used in this context to advance a conciliatory argument of tolerance and co-existence based on shared understandings of humanism as the bedrock of both Hinduism and Islam.

The issue of script, then, was inextricably bound up with both the mechanics of modernity and the discourses of modernisation. Inseparable from the milieu of the colonial encounter, it came to dominate the late nineteenth-century debates on the language of administration in the courts of the North West Provinces \& Oudh, and was to become the irreconcilable difference par excellence in the Hindi-Urdu debate from that point on. ${ }^{9}$

Yet despite all this, the possibility that a way might be found to reconcile Hindi and Urdu to one another, along with their communities of writers, readers, and speakers, remained an attractive one to some at least. Seeing potential in the name, and seeking forums in which the same could be encouraged, they came together in literary gatherings,

\footnotetext{
${ }^{5}$ See, in addition to the studies already mentioned, David Washbrook, “To each a language of his qwn': Language, culture, and society in colonial India' in Penelope J. Corfield (ed.) Language, history, and class, Oxford, Blackwell, 1991, pp. 179-203; Bernard Cohn, 'Command of language and the language of command', in Ranajit Guha (ed.) Subaltern studies IV: Writings on South Asian history and society, New Delhi, OUP, 1985, pp. 276-329; David Lelyveld, 'The fate of Hindustani: Colonial knowledge and the project of a national language', in Carol A. Breckenridge and Peter van der Veer (eds.) Orientalism and the postcolonial predicament, Philadelphia, University of Pennsylvania Press, 1993, pp. 189-214; and, most recently and comprehensively, Alison Safadi, 'The Colonial construction of Hindustani: 1800-1947', PhD dissertation, Goldsmiths, University of London, 2012.

${ }^{6}$ Orsini, Hindi public sphere, pp. 359-60.

${ }^{7}$ Lelyveld, 'The fate of Hindustani'.

${ }^{8}$ Alok Rai, 'The persistence of Hindustani', Annual of Urdu Studies 20, 2005, pp. 135-44, p. 140.

${ }^{9}$ See King, One language, for a full discussion of the issue of script.
} 
This is the version of the article accepted for publication in Modern Asian Studies published by Cambridge University Press: https://www.cambridge.org/core/journals/modern-asian-studies/all-issues

Accepted version downloaded from SOAS Research Online for private research and study only:

http://eprints.soas.ac.uk/23095/

wrote alternative literary histories and employed novel strategies of quotation and representation. The question was not solely the preserve of high politics-such is the conceit at the heart of Manto's story - and an investigation of other realms, here literary instutitions and poetry, while occasionally frustrating, has much to offer.

\section{The Hindustani Academy}

Established in 1927 by an Act of the Legislative Assembly of the United Provinces, inaugurated in Lucknow and eventually based in Allahabad, the Hindustani Academy as an institution was located geographically, temporally, interpersonally, and almost existentially at the very heart of the Hindi-Urdu controversy, which raged most fiercely in the north Indian heartland. ${ }^{10}$ The origins of the Academy and the motivations behind its establishment demonstrate conclusively the faith of litterateurs, politicians, and educationalists in the efficacy and importance of such institutions to attain both literary and societal progress. ${ }^{11}$ The Academy and its publications were intended to promote the expansion and enrichment of literature in both Hindi and Urdu, but at the same time they tried, in a somewhat vaguely defined manner, to arrest or at least retard the ongoing distancing of Hindi and Urdu, and their users, from one another.

However, the history of the Academy, its efforts, activities and attendant controversies, suggests that any such faith in the Academy as an instrument of literary and linguistic - and thereby communal-reconciliation may have been misplaced. Confusion and contestation over the name itself- 'Hindustani' as an adjective for Indian, or a linguistic label defining a language or register in contradistinction to either Hindi or Urdu - in many ways prefigured intense disagreements over the aims and objectives of the institution: to promote Hindi and Urdu as so-called 'twin vernaculars', ${ }^{12}$ or to evolve, create, or even recover a separate and unitary form of the two languages as both a tool of linguistic, literary, and communal reconciliation and a compromise candidate for the role of national language. Indeed, the wide divergence of opinion regarding 'Hindi, Urdu, and Hindustani' among Academy

${ }^{10}$ The Academy's origins lay in plans for a translation bureau attached to the Ministry of Education of the United Provinces government, making it a quasi-official body. In time, the proposed institution outgrew this rather limited conceptualisation, and became for its proponents an important tool in the wider and interlinked projects of literary and linguistic enrichment, education, and societal progress.

${ }^{11}$ Writing the editorial of the first issue of the Academy's twin Hindi and Urdu journals, both called Hindustān̄i, Dr Tara Chand, History professor at Allahabad University and the Academy’s General Secretary, traced the histories of various notable academies - from those of Plato and Aristotle, those of the Medici family during and after the fifteenth century in Florence, Richelieu's L'Académie Française, and the Royal Societies and British Academy in England—and situated the Hindustani Academy in this genealogy. But he also emphasised the Indian context, suggesting not just a universal relevance, but also a particular timeliness:

Hindi: Is dhā̄ hazār baras ke itihās se patā caltā hai ki ekedemī kā sthāpit honā jātiyom kī unnati mem ek viśeș mahattva rakhtā hai. Pratyek jāti ke itihās mem ek samay ātā hai jab jāti ke netāom ko yah anubhav hotā hai ki jũān aur sāhitya kā āśray jātīy lābhom kī rakșā ke liye āvaśyak hai.

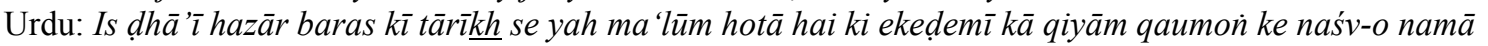
men $\underline{k h a ̄ s ̣ ~ a h m i y a t ~ d i k h t a ̄ ~ h a i . ~ H a r ~ q a u m ~ k i ̄ ~ t a r i ̄ k h ~ m e n ̃ ~ e k ~ z a m a ̄ n a ~ a ̀ t a ̄ ~ h a i ~ j a b ~ r a h n u m a ̄ i y a ̄ i n-e ~ q a u m ~ k o ~ y a h ~}$ ehsās hotā hai ki 'ilm-o adab kī sarparastī qaumī mufād kī hifāzat ke li'e zarūrī hai.

Two and a half thousand years of history show that the establishment of academies retains a particular importance in the progress of a people. A time comes in the history of every people when the leaders of that people realise that patronage of learning and literature is essential in order to secure the prosperity of the people.

'Sampādakīya', in Hindustān̄̄ (Hindi) 1, 1, January 1931, pp. 118-27, p. 126, and 'Adārīya', in Hindustān̄̄ (Urdu) 1, 1, January 1931, pp. 142-52, p. 151.

${ }^{12}$ The phrase is William Marris', then Governor of the United Provinces, at the inauguration of the Academy. Reproduced in Tara Chand, Report, pp. 79-88. 
This is the version of the article accepted for publication in Modern Asian Studies published by Cambridge University Press: https://www.cambridge.org/core/journals/modern-asian-studies/all-issues

Accepted version downloaded from SOAS Research Online for private research and study only:

http://eprints.soas.ac.uk/23095/

contributors reflects the ambiguity of the Academy's institutional policy: thus, Tara Chand could stress the inclusivity of Hindustani as a register that already contained all but the most extreme (or excessive) variants of Sanskritized Hindi or Persianized Urdu; while Dhirendra Varma dismissed it as hopelessly simple, 'everyday', and incapable of being a literary language - both while writing in the same institutional journal! ${ }^{13}$ Varma went further: while he took what has been described as a 'pragmatic approach' to the question of Hindi as the national language, advocating its status as rājbhasṣa (official language) rather than rāștrabhaș̣a (national language), ${ }^{14}$ his moderate stance was, however, both relative and internal to an exclusively defined Hindi sphere, rather than a more broadly conceived Hindustani sphere. Hindustani in his view was a term invented by Europeans and applied at first to formal Urdu and later to conversational Urdu; for him Hindustani remained an intrinsically vacuous term, and in practice hopelessly predisposed towards Persian vocabulary, forms, and aesthetics. ${ }^{15}$ Varma's really quite partisan publication seems almost incongruous in the context of an Academy devoted, at least in theory, to the breaking down of distinctions between Hindi and Urdu and their practitioners. His approaches to literary and linguistic history did little to advance such an agenda - in fact, they mandated quite clearly against it.

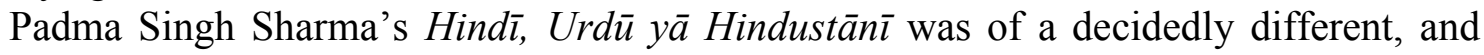
perhaps more typical, order. In this book, Sharma certainly issued a plea for unity, and his assertions with regard to language were clearly sincere, but this was a rhetorical rather than literary work, which did not demonstrate a literary possibility, but simply argued for it. The book was a compilation of a series of lectures that Sharma delivered under the aegis of the Academy in 1932, in which he espoused the fundamental and original unity of Hindi and Urdu, and made suggestions on how such unity might be re-established, particularly through the work of 'farsighted scholars'. ${ }^{16}$ His concluding remarks were a both a validation of the Academy's work and mission, and a rallying cry for the cause of HindiUrdu unity. The Hindustani Academy had been founded, as was obvious from its name, to make the case for Hindustani as a paradigm in which the enmity and disharmony between Hindi and Urdu could be erased as from members of the same family, and this was a worthy effort:

Yadi ekeḍmī in donom ko ek karne mem samarth ho sakī, to hindustān par uskā baṛā upkār aur ahsān hogā. Kuțumb ke bațvāre kī tarah bhāṣā kā yah bațārā bhī kuṭmb-kalah aur sampatti-vināś

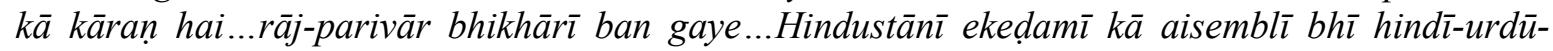
parivār ke lie koì aisā hì qanūn yā niyam banā sakī, jisse yah donomi, vibhakt na ho sakem, to bhāsāa

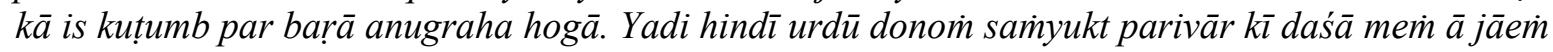
to phir iskī sāhitya-sampatti kā kō̄ bhāṣā muqābilā na kar sake.

\footnotetext{
${ }^{13}$ See: Tara Chand, 'Hindustānī ke sambandh men kuch ghalatfahmiyān', Hindustān̄̄ (Hindi) 7, 3, April 1937, pp. 279-97; Dhirendra Varma, 'Hindī, Urdū, Hindustānī', Hindustānī (Hindi) 4, 3, July 1934, pp. 195200.

${ }^{14}$ Orsini, Hindi public sphere, p. 135. See also her discussion of Hindustani in ibid., pp. 358-65.

${ }^{15}$ Dhirendra Varma, Hindī bhāṣā aur lipi, Allahabad, Hindustani Academy, 2005 [1938], p. 45. Varma's critique of the vacuity of Hindustani finds resonance in, for example, the discussion of the term in the context of Hindi films: see Harish Trivedi, 'All kinds of Hindi: The evolving language of Hindi cinema', in Vinay Lal and Ashis Nandy (eds) Fingerprinting popular culture: The mythic and the iconic in Indian cinema, New Delhi, OUP, 2006, pp. 51-86.

${ }^{16}$ He mentions Dhirendra Varma in this connexion, praising in particular his stance regarding Hindi as

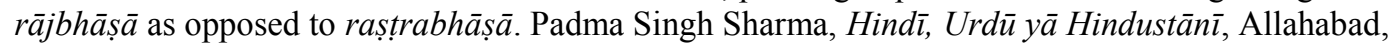
Hindustani Academy, 1932, pp. 34-5.
} 
This is the version of the article accepted for publication in Modern Asian Studies published by Cambridge University Press: https://www.cambridge.org/core/journals/modern-asian-studies/all-issues

Accepted version downloaded from SOAS Research Online for private research and study only:

http://eprints.soas.ac.uk/23095/

If the Academy proves capable of making these two into one, it will be a great kindness and favour for India. Like a schism in a family, this schism is the cause of family strife...the national family has become divided... If the assembly of the Hindustani Academy could make such a law or rule according to which these two could not be separated, this would be a great support to this language family. If Hindi and Urdu should come together as one joint family then no language in the world would be their literary equal. ${ }^{17}$

For Sharma, then, the role of the Academy was clear: its mission was to preserve a preexisting language and mode and prevent a new and decidedly unfortunate process of differentiation.

These are two almost mutually-exclusive viewpoints, both by prominent members of the Academy and published by it. Yet it was precisely this strategic ambiguity that allowed the Hindustani Academy to function as a 'big tent', incorporating and involving key players from across the linguistic and ideological spectrum in a broad project of literary and societal enrichment of which the question of language was but one aspect.

While the Academy claimed a remit over cultural production in the broadest sense in both Hindi and Urdu (convening literary conferences, commissioning reports, awarding prizes), its primary activities were in the realm of publishing - not only of books but also, from 1931 onwards, of its two journals. Almost half of the books published by the Academy in its first thirteen years were literary or linguistic in nature. These included literary translations and poetic anthologies, as well as literary editions and biographies, and several significant interventions in the Hindi/Urdu question. The picture that emerges from these publications is of a complex situation in which no clear strategy is immediately discernible.

If the Academy's writings on literary history did little to challenge the dominant binary and oppositional construction of separate linguistic and literary heritages for separate religious communities, ${ }^{18}$ another set of publications reveals not only a commitment to Hindi-Urdu unity but a belief on the part of many of the Academy's members/activists in the pre-existence of 'Hindustani' as a linguistic model and a mode of inter-communal literary commonality. In particular, the Hindi and Urdu translations produced under the aegis of the Academy by prominent litterateurs of socially relevant literary texts drawn from contemporary and historical European literary traditions show a conscious attempt to bolster such a paradigm with working models of an easily understood, mutually intelligible

${ }^{17}$ Ibid., pp. 151-2, emphases added. Sharma's use of the motif of a divided family would have had a strong resonance among members of his audience.

${ }^{18}$ E.g. Shyam Sundar Das' edition of Satsā̄ Saptak (1931, Hindi), Lala Sita Ram's edition of Mahatma Akshar Ananya's Prem Dīpikā (1936, Hindi), or Jalil Ahmad Qidwai’s Dīvān-e Bedār (1937, Urdu): Avadhi writers such as Tulsidas and Biharilal were slotted into the Hindi canon and their works published in Devanagari, while Bedar's Urdu verse remained confined to the Urdu script and tradition. The same is true for the literary biographies published by the Academy in its early period (in Hindi: Tulsidas, Bhartendu Harishchandra, and Sant Tukaram; in Urdu: the famous iconoclast and contested icon, Kabir), and for the articles in the Hindi and Urdu versions of the journal Hindustānī. Literature-related articles in the Urdu Hindustān̄ tended to focus on figures such as Sauda, Mir, Hali, Ruswa, and Ghalib, and on subjects such as modern Urdu poetry, Urdu literary histories, other Urdu journals, and so forth. There were only occasionally articles on elements of the Hindi canon, and even what we could term "Hindu themes" were most often considered from the point of view of their relation to Urdu. The opposite situation applied to the Hindi journal. See, for example, Shah Mu'in ud-Din Ahmad Nadvi, 'Urdū Śā'irī men̉ Hindū Kalcar aur Hindustān ke Tab'ī aur Jughrāfī Așrāt', Hindustānī (U), 9, 3 (July 1939); Shah Mu'in ud-Din Ahmad Nadvi, 'Urdū Śā'irī men̉ Hindū Kalcar aur Hindustān ke Țab'ī aur Jughrāfī Așrāt’, Hindustānī (U), 9, 3 (July 1939); Bhagvatdayal Varma, 'Fārsī lipī memi hindī pustakem’', Hindustān̄ì (H) 3, 4 (October 1933) 378-86. Important exceptions to this general trend exist, such as Upendranath Ashk's articles (see below). 
This is the version of the article accepted for publication in Modern Asian Studies published by Cambridge University Press: https://www.cambridge.org/core/journals/modern-asian-studies/all-issues

Accepted version downloaded from SOAS Research Online for private research and study only:

http://eprints.soas.ac.uk/23095/

register. Some important examples were G. E. Lessing's Nathan der Weise (Nathan the Wise, 1739), already long-considered, in the words of Aamir Mufti, 'the exemplar of the Enlightenment attitude towards religious co-existence and tolerance'; ${ }^{19}$ and John Galsworthy's Strife (1909) — on relations between low-paid factory workers and their managers - and Justice - a pointed critique of the Edwardian penal system, and particularly of the practice of solitary confinement. Such works would have had an obvious appeal to reform-minded writers such as Premchand, who produced several of the Hindi translations, and to the secularly oriented editor Daya Narain Nigam and historian Tara Chand, both of whom were involved in the project, and their themes emphatically demonstrate the progressive inclinations of those involved at the heart of the Academy's operations. ${ }^{20}$ Tara Chand daringly, if obliquely, invoked the resonance of such plays in the contemporary Indian context in his introduction to Hartāl. He noted that there was no shortage of plays in Hindi and Urdu at the time, but he looked to Europe and especially to the political turmoil of the nineteenth century as a fertile period for dramatic creativity, when 'the pride of man...newly self aware, trod new paths of freedom and equality. ${ }^{21}$

But apart from representing models of socially committed and secular or at least religiously neutral works, the translations into Hindi and Urdu, with their almost identical and overlapping register, were also intended as linguistic models for literary worksexemplars of the idiomatic and mixed register in which Hindi or Urdu works could and should be composed. This 'Hindustānī bhāṣă' was intended as an overlapping and inclusive register, with distinctions and artificially 'pure' vocabulary rigorously avoided. Indeed, a brief example drawn from the translations of Lessing's Nathan shows how limited the differences need be. Nathan is perhaps best known for the structurally and narratively central parable of the ring, through which the 'wise' Jew Nathan demonstrates the equality of Islam, Judaism and Christianity to the questioning Sultan Saladin. Saladin asks Nathan which of the three religions is the true one, to which Nathan responds with the story of a man who, possessing a ring which made him beloved by God and men, determined that he would give the ring to his favourite son. Unable to choose between them, he had two copies made, and gave each of his three sons a ring, telling each that his was the true one. On his death, the three approached a judge to settle the argument as to which ring was genuine, and thus which of them was their father's favoured son. This central scene culminates in the poetic denouement of the parable: 'Umsonst; der rechte Ring war nicht / Erweislich Fast so unerweislich als / Uns jetzt - der rechte Glaube.' ('And so, the true ring could not be determined - almost as indeterminable as is, for us, the true faith.') The German passage was rendered as follows in Hindi:

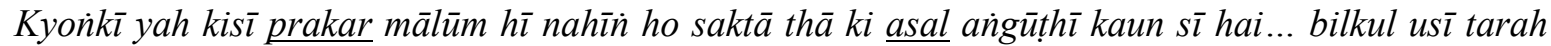
ham bhì is samay yah nirnay nahïn kar sakte ki saccā dharm kaun sä hai. [p. 152]

\footnotetext{
${ }^{19}$ Aamir Mufti, Enlightenment in the colony: The Jewish question and the crisis of postcolonial culture, Princeton, Princeton University Press, 2007, p. 45.

${ }^{20}$ The number of literary translations produced was not large: by 1939, after twelve years of operation, the Academy had published only nine, two plays by the eighteenth-century German writer Gotthold Ephraim Lessing (Nathan der Weise (1779): Urdu tr. Muhammad Naimur Rehman as Nātan in 1930, and in Hindi by Mirza Abul Fazl in 1932; Minna von Barnhelm (1767): Hindi tr. Mangal Deo Shastri as Mīnā in 1937) and four plays by the contemporary English dramatist and novelist John Galsworthy (Justice (1910): Hindi tr. by Premchand as Nyāya in 1930 and Urdu tr. by Daya Narain Nigam as Insāf in 1939; Skin Game (1920): Urdu tr. by Jagat Mohan Lal Rawan as Fareb-e Amal in 1930, and Hindi tr. by Lalit Prasad Shukla as Dhokā Dhārī in 1931); Strife (1909): Hindi tr. Premchand as Hartāl in 1930; The Silver Box (1906): Hindi tr. by Premchand as Chāndī ki Dibyā, 1930). Galsworthy would receive the Nobel prize for literature in 1932.

${ }^{21}$ Tara Chand, 'Nivedan', in Premchand (tr.) Hartal, pp. 4-5.
} 
This is the version of the article accepted for publication in Modern Asian Studies published by Cambridge University Press: https://www.cambridge.org/core/journals/modern-asian-studies/all-issues

Accepted version downloaded from SOAS Research Online for private research and study only:

http://eprints.soas.ac.uk/23095/

This was a minor reworking of the Urdu:

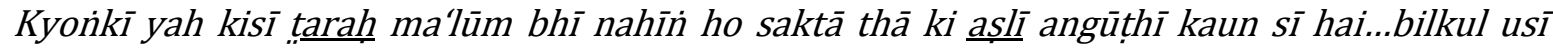
țarạ ham bhì is vaqt yah faișlah nahìn kar sakte ki saccā dīn kaun sā hai. [p. 221]

Beyond being an eloquent advocacy of religious equivalence (sarva dharma samabhāva, perhaps?), the fundamental linguistic similarity of the two passages is clear. ${ }^{22}$

Also symptomatic of the 'broad tent' policies pursued by the Academy are those other publications that were inclusive in their approach or paradigm shifting in their presentation,

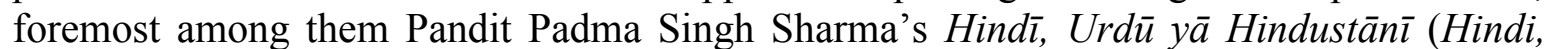
Urdu or Hindustani, 1932), ${ }^{23}$ and Upendranath Ashk's Urdū kāvya kī ek naī dhārā (A new trend in Urdu poetry, 1941; 1949), on which more below.

Finally, we should also briefly consider the Academy's drive to establish its claim of authority, tempered with impartiality, over the Hindi and Urdu literary fields, as evidenced by the decision, on the occasion of its very first meeting in Lucknow on 30 March 1927, to set up two language survey committees, one each for Hindi and Urdu, to assess the state of each language's literature, and to provide recommendations to the Academy on what actions would be appropriate and expedient. ${ }^{24}$ Perhaps the most striking recommendation in the Urdu report is the very first proposal made the authors, who conceived of the Academy's chief role as facilitating 'writing and reconciliation', that the Academy should do everything in its power to create a 'dāru'l-tâlīf'-literally, an 'abode of reconciliation'. ${ }^{25}$

The Academy's lack of a clear position on the central issues of the nature of Hindustani as a language, register or discourse and, second, on the role of the institution should be

${ }^{22}$ If we ignore the slippage between asal in the Hindi and $a s ̦ l i \overline{i n}$ the Urdu, there are only 4 variations: prakar/tarah for way or method (though it should be noted that tarah is used later on in the Hindi passage); samay/vaqt for time; nirnay/faișlah for determination; and dharm/din for faith. These slight changes are significant precisely because they are so slight. Even more significant are the moments of continuity: the Persianate mālum honā remains consistent in both iterations, as does the Indic angūthi , and of course the broader syntactical and grammatical framework is identical. Fundamentally, the high poetic style of Lessing's work was rendered here in easily understood prose, with a minimum of lexical and syntactical variation.

${ }^{23}$ See also Tara Chand's remarks on Hindi and Urdu in the introduction to Ashk's volume, the clearest articulation of Hindi and Urdu as both shared languages and literary traditions, the patrimony of both Hindus and Muslims:

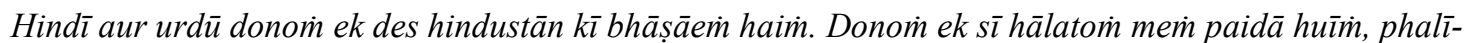
phūlī aur baṛ̂̄ hai. Donom kā adab hindū aur musalmān likhnevālom kī kośiśom se banā hai...Hindī

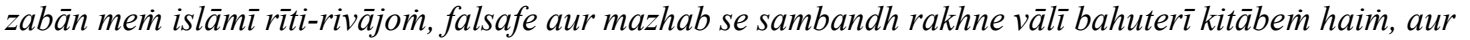

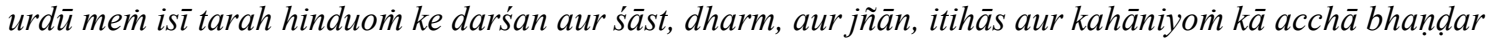
hai.

Hindi and Urdu are both languages of one country, India. Both were born in the same conditions, blossomed and grew. The literature of both is made from the efforts of Hindu and Muslim writers...There are excellent books concerning Islamic customs, philosophy and religion in the Hindi language; and in this same manner there is a treasure trove of Hindu philosophy and scripture, religion and science, history and stories in Urdu. (emphasis added)

${ }^{24}$ These reports were to be completed and submitted to the executive within two months, and both were subsequently published. Syed Zamin Ali (ed.) Urdū zabān aur adab, Allahabad, Hindustani Academy, 1927, from the introduction to which the above information is drawn, and Lala Sita Ram (ed.) Hindī sarve kamīt $\bar{\imath} \bar{\imath}$ ripart, Allahabad, Hindustani Academy, 1930. I have thus far been unable to trace a copy of the Hindi Committee's report, and so any discussion is regrettably lopsided. We can only wonder, at this stage, as to why the Hindi report was published three years after its Urdu counterpart.

${ }^{25}$ Ibid., p. 39. 
This is the version of the article accepted for publication in Modern Asian Studies published by Cambridge University Press: https://www.cambridge.org/core/journals/modern-asian-studies/all-issues

Accepted version downloaded from SOAS Research Online for private research and study only:

http://eprints.soas.ac.uk/23095/

regarding the creation, resurrection or encouragement of such a mode-what I call the 'strategic ambiguity' or indeterminacy of the Academy - probably facilitated the inclusion within the ambit of the Academy of a broad range of literary figures and opinions. In the end, though, it was this self-same strategic indeterminacy that precluded the Academy from ever being able to make any authoritative interventions in the Hindi-Urdu controversy. It is tempting then to adjudge the Academy a failed project, as the creation of a truly mixed and formally recognised language of Hindustani as particularly a literary language never came about. I suggest, however, that its significance was simultaneously less formal and more fundamental. It revealed widespread interest within the literary establishment in arresting the increasing bifurcation of Hindi and Urdu and the attendant processes of communal identification. And it provided an institutional and semantic space for the development of a rhetoric of linguistic and literary commonality that had hitherto been lacking.

\section{Poetic tastes and practices across the divide}

Poetry was the both historically and contemporarily preeminent form of literary production in the subcontinent. The production and consumption of Hindi and Urdu poetry, I argue, did not take place in isolation from one another. A significant number of poets who we might now conveniently label as either 'Hindi' or 'Urdu', were aware of, and participated in, a field of poetic production that encompassed a broad and overlapping Hindi-Urdu ecumene, and it was in this context that debates over poetic tradition and the evolution of new forms of taste and practice took place. ${ }^{26}$ This section examines the Hindi and Urdu poetry of the early twentieth century together as produced and consumed in literary journals of the period in order to look for evidence of commonality. Yet the picture that emerges is an uneven one.

Let us begin with literary history and canon formation. Existing scholarship has shown how literary histories were directly implicated in the communal polarisation of Hindi and Urdu and in the construction of exclusive canons. ${ }^{27}$ Were then any attempts at crossing this divide? An interesting example is the nine-part 'Bhâśa aur uske nauratan' ('Bhasha and its Nine Jewels'), a series of articles on major Hindi poets that ran from 1924-7 in Daya Narain Nigam's Urdu journal Zamāna and included Surdas, Tulsidas, Keshavdas, Biharilal, and Bhartendu Harischandra. The author was Manzur ul-Haq Azamgarhi, though it seems clear that he drew his schema from elsewhere-probably Shyambihari and Ganeshbihari Mishra's book Hindī Navaratn, a Hindi canonising work. ${ }^{28}$ These articles were full of

\footnotetext{
${ }^{26}$ Some studies stand as important exceptions to this general rule. Nirala's poetic diversity and experiments with Urdu are well known. As Hoynacki tells us, Nirala composed ghazals as well as bhajans and gitt, was comfortable with Urdu vocabulary and used it extensively in some of his compositions (see George John Hoynacki, 'Suryākant Tripāthī 'Nirālā' and the Chāyāvād school of Indian literature (1920-1935): an investigation and analysis of Nirālā's poetry and his impact upon literary movements in Indian literature', $\mathrm{PhD}$ dissertation, University of Minnesota, 1980, pp. 25-31). David Rubin also stresses his linguistic expansiveness: David Rubin, 'Nirala and the Renaissance of Hindi Poetry', The Journal of Asian Studies, 31, 1, November 1971, pp. 111-26. Another particularly noteworthy example is Sagaree Sengupta's study of Bharatendu Harishchandra's Urdu verse, in which she demonstrates this Hindi advocate's 'continued and profound involvement with the language [Urdu] at the creative level'. Sagaree Sengupta, 'Krishna the cruel beloved: Harischandra and Urdu', Annual of Urdu Studies 9, 1994, pp. 82-102, p. 87.

${ }^{27}$ See Frances W. Pritchett and Shamsur Rahman Faruqi (eds and trs) Āb-e Hayāt: Shaping the canon of Urdu poetry, New Delhi, OUP, 2001; also Orsini, Hindi public sphere.

${ }^{28}$ Shyambihari and Ganeshbihari Mishra, Hindī navaratn [first ed. 1967 VS (1910-11 AD)]. While seven of the poets correspond, though the order is slightly difference there are two parts to the Mishra collection (the Tripathi brothers and Kabir) that were replaced by Azamgarhi (with Bhushan and Mati Ram). The absence of Kabir is perhaps the most striking divergence, but one can only speculate on the reason behind it.
} 
This is the version of the article accepted for publication in Modern Asian Studies published by Cambridge University Press: https://www.cambridge.org/core/journals/modern-asian-studies/all-issues

Accepted version downloaded from SOAS Research Online for private research and study only:

http://eprints.soas.ac.uk/23095/

praise for the Bhasha poets: Surdas' corpus was described as a jewel of Bhasha poetry; ${ }^{29}$ Keshavdas was said to rank close behind Sur; ${ }^{30}$ Bhartendu Harischandra was described as the 'bādśăh' of both poetry and prose ('nazm-o nassr ke'), ${ }^{31}$ and Biharilal was said to be comparable to Ghalib in his expressiveness. ${ }^{32}$ If we consider the presentation of the poetry in these articles, all of them contained quotations of the various poets' couplets in Devanagari along with Nastaliq transliterations and Urdu glosses. Azamgarhi's consistency in this regard is not matched in other articles that appeared in the same journal on Braj, Hindi or Sanskrit themes: some pieces provided Devanagari originals, at times with Nastaliq transliterations and/or Urdu translations, sometimes with both, and sometimes with neither. ${ }^{33}$ The presence of transliterations and/or translations suggests that some authors expected their readers to need aid, though their differing approaches are evidence of differing expectations. By contrast, quotations without translation and/or transliteration demonstrate that other authors expected at least a working knowledge of the Devanagari script and/or the Braj (or Avadhi) language. ${ }^{34}$ This all points to a multilingual competency among a variety of people - editors, authors, engravers, and subscribers - while at the same time indicating a degree of uncertainty as to precisely what level of competency could be reasonably assumed in the readership.

Besides this interesting ambiguity regarding presentation and expectations, another fact stands out: Azamgarhi's pieces are all rather introductory in terms of their style and content. They seem intended to introduce the unfamiliar texts of the work of already familiar authors. At the same time, articles on Persian and Urdu poetry were a consistent, if not overly common, feature of Zamāna over the years. Written by both Hindus and Muslims, articles on Persian poetry covered a range of poets from old Iranian classics to more recent Indian writers. ${ }^{35}$ Past masters of Urdu poetry, and their compositions replete with the same expressions and conventions as those derided by critics from Azad to Ram Babu Saksena, also made regular appearances in the pages of Zamāna, from Mir to Ghalib, from Sauda to Dagh. More often than not, these poets and their works were presented without any special justification: appreciation of the old was evidently not considered particularly remarkable. At other times, authors felt the need to pre-emptively defend the

\footnotetext{
${ }^{29}$ Manzur ul-Haq Azamgarhi, 'Bhāśā aur uske nauratan: 2 - Sūrdās' in Zamāna 42, 2, February 1924, pp. 97105, p. 105.

${ }^{30}$ Azamgarhi, 'Bhāśā aur uske nauratan: 4 - Keshavdās' in Zamāna 42, 5, May 1924, pp. 278-286.

${ }^{31}$ Azamgarhi, 'Bhāśā aur uske nauratan: 9 - Hariścandra' in Zamāna 49, 4, October 1927, pp. 169-178, p. 169.

${ }^{32}$ Azamgarhi, 'Bhāśā aur uske nauratan: 5 - Bihārīlāl' in Zamāna 43, 5, November 1924, pp. 209-218, p. 209.

${ }^{33}$ See, for example, Munshi Harikishan, 'Rahīm ke dohe', pp. 24-7; Sayyid Maqbul Husain Ahmad Yuri, 'Rahīm ke dohe', pp. 28-36; Pandit Harve Narayan Pandey, 'Surdās', pp. 37-42; Iqbal Varma Sahar Mahatgami, 'Bharateṇdu Hariścandra', pp. 51-7, in Dayā Narā'in Nigam ke risāla 'Zamāna' Kānpur (19031942) se intikhāb 21: Hindī adabiyat, Patna: Khuda Bakhsh Oriental Public Library, 1994.

${ }^{34}$ The position of Braj in the early twentieth century is a complex one, as Valerie Ritter has shown in her study of Jagannath Das 'Ratnakar' and Ayodhyasingh Upadhyay 'Hariaudh'. She suggests, convincingly, that 'Braj Bhasha poetry came to inhabit a mixed oral and print culture with metamorphosing definitions of the literary public', and that poets of Braj, particularly Hariaudh and Ratnakar, 'considered it a unifying poetic mode across other inexorably widening divisions'. Hariaudh in particular used variously Sanskritised Hindi and a variety of courtly Braj and idiomatic registers in his compositions. Valerie Ritter, 'Networks, patrons, and genres for late Braj Bhasha poets: Ratnakar and Hariaudh', in Francesca Orsini (ed.) Before the divide: Hindi and Urdu literary culture, New Delhi, Orient Blackswan, 2010, pp. 249-76, pp. 251, 253.

${ }^{35}$ For a selection of these articles, see Dayā Narā'in Nigam ke risāla...se Intikhāāb 23: Adabiyāt-e Fārsī, Patna, Khuda Bakhsh Oriental Public Library, 1995.
} 
This is the version of the article accepted for publication in Modern Asian Studies published by Cambridge University Press: https://www.cambridge.org/core/journals/modern-asian-studies/all-issues

Accepted version downloaded from SOAS Research Online for private research and study only:

http://eprints.soas.ac.uk/23095/

old poets from any suggestion that their work did not meet modern standards. ${ }^{36}$ The same pattern obtained in other Urdu journals, such as the Lahore journal Makhzan, edited by Sir Abdul Qadir. It was a tremendously influential literary publication, and well known for publicising new Urdu literature; this was after all the journal in which Iqbal published much of his verse, beginning in the very first edition of the magazine in 1901 and continuing for many years. ${ }^{37}$ Qadir was deeply committed to the advancement of Urdu literature (he presided over the Punjab Literary League for several years), but also to the use of literature to ameliorate or solve the social problems that India faced. ${ }^{38}$ Accordingly, advocacy of reform was rarely absent from the pages of Makhzan, whether in the form of studies (or even poems) on the life and work of reformers such as Hali, ${ }^{39}$ or in a wide range of poems that, in one way or another, demonstrated the new directions that Urdu poetry was taking. Yet at the same time, the taste for and interest in the old never went away: Ghalib, Aatish and even Amir Khusrau made regular appearances as the subjects of articles, ${ }^{40}$ and other articles on a wide variety of subjects-literary or otherwise-were regularly interspersed with couplets from these and other great poets. ${ }^{41}$ 'Classical' poetry was therefore not just an object of study, but a key component of the affective and rhetorical vocabulary of these writers.

The fact that 'classical' Urdu verse appeared also in several Hindi journals of the period is all the more striking, given the apparent strengthening of distinctions between the two print worlds. The column titled 'Kesar kī kyārī' - literally flowerbed, and quite apparently a Hindi rendering of the common Urdu poetic image gulśan - in the Hindi monthly Cāmd, featured Urdu couplets selected by Sukhdeo Prasad 'Bismil' Ilahabadi and, while ranging widely, regularly featuring compositions by him, his ustād Nur Narvi, and the latter's own ustād, Dagh Dehlavi. ${ }^{42}$ This selection is further noteworthy as it constituted an artistic and aesthetic statement in favour of a certain formalism in Urdu poetry, standing against reformist ideas. Further, almost every aspect of its presentation of Urdu poetry points towards an aesthetic experience that was emphatically meant to be luxurious and indulgent, quite contrary to the norms of progressive literary values.

[INSERT FIGURE 1 NEAR HERE. LEGEND: Figure 1. The graphic headline for the poetry selections of Bismil Ilahabadi that appeared in Cāmd.]

\footnotetext{
${ }^{36}$ E.g. Babu Shyam Mohan Lal 'Jigar' Barelvi, 'Kalām-e Mīr': 'forming an opinion of them according to modern tastes is a fundamental mistake, because at that time Urdu poetry was establishing the preliminary way houses on the road of progress'; in Zamāna 52, 6, June 1929, p. 1.

${ }^{37}$ Qadir wrote the introduction to Iqbal's first collection of poetry, Bāng-e Darā, in which he explained his role not only in encouraging Iqbal to publish (Makhzan carried at least one of his poems every month from 1901 until his departure for England in 1905, and printed many more after his return), but also, along with Thomas Arnold, in discouraging Iqbal from abandoning poetry altogether. See Muhammad Iqbal, Bāng-e Darā, Lucknow, Al-Nazir Book Agency, 1926. On the whole, Makhzan had relatively few Hindu contributors compared to Zamāna: the poet Hari Chand 'Akhtar' is a notable exception in this regard, though there were other Hindu poets and contributors involved.

${ }^{38}$ See his introduction to Bāng-e Darā.

${ }^{39}$ See, for example, in Makhzan: Saiyid Ahmad Dahlavi, 'Khwāja Ḥālī’ (May 1915) pp. 13-29; 'Nazar', 'Marșiya śams al-'ulamā maulānā knhwāja Alțāf Husain șāḥab Ḥālī marhūm' (March 1915) pp. $73-5$.

${ }^{40} \mathrm{See}$, for example, the multi-part series by 'Azarda' Sitapuri, 'Ātiś-o Ghālib' in Makhzan (April-June 1918), among many others.

${ }^{41}$ Qadir's own writing exhibited this tendency: see, for example, Abdul Qadir, 'Jab Ātiś javān thā' in Ahmad Salim ed. Intikhāb-e Makhzan, Lahore, Sang-e-Meel Publications, 2004, pp. 23-6.

${ }^{42} C \bar{a} \dot{m} d$ also published an Urdu version. The genre of collected poetic couplets and short extracts represented by 'Kesar' deserves further exploration across journals, but certainly seems to represent an attempt to evoke the performative aspects of poetic recititation, as well as a demonstrable reluctance to abandon entirely the enjoyment of Urdu verse.
} 
This is the version of the article accepted for publication in Modern Asian Studies published by Cambridge University Press: https://www.cambridge.org/core/journals/modern-asian-studies/all-issues

Accepted version downloaded from SOAS Research Online for private research and study only:

http://eprints.soas.ac.uk/23095/

The process of canon formation was, as Orsini has demonstrated with regard to Hindi, directly dependent on the formal and institutional arrangements of education, in university syllabi and textbook production; it was in such contexts as these that literary canons were established and reproduced. In contrast, journals such as those discussed here provided a space to imagine an alternative canon, intimately bound up with issues of the creation of tastes and literary habitus, which transcended the divides of script and the increasing congruence between identifiers based on language and religious affiliation.

In this partly overlapping world of Hindi and Urdu poetics, two figures from this period stand out for their forthright advocacy of looking beyond the simplistic taxonomies of script, and for practising what they preached. The first of these, Miraji (1912-49) would commonly be described as an Urdu poet, but was one who 'brought Braj, Awadhi, Hindi, Maithili back to Urdu' through his poetry, particularly his gitt. ${ }^{43}$ The second is Upendranath Ashk, who in two 1938 articles in the Hindustani Academy Hindi journal that also appeared

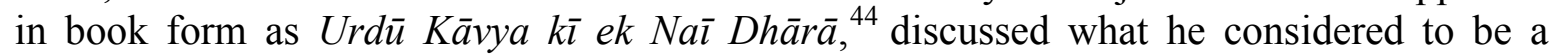
significant positive shift in the oeuvre and outlook of some Urdu poets: a simultaneous move away from the traditional concerns and structures of classical Urdu poetics and an increasing acceptance of and openness to the influence of Hindi and other poetic traditions, exemplified in the pioneering works of 'Hafiz' Jalandhari, 'Josh' Malihabadi, and Miraji. As a writer and future publisher whose linguistic and literary habitus included Urdu, Punjabi, and Hindi, Ashk was involved in anthologising and representating Urdu literature in Hindi throughout his life. He edited and published not only Sanket, but also several other volumes of poetry in the $1960 \mathrm{~s} .{ }^{45}$

The majority of the Ashk's two articles is taken up with poetic quotations - samplings of verse that Ashk had gleaned from a variety of Urdu journals and used to illustrate aesthetic and formal developments in Urdu poetry across an impressively wide range of themes. The first of these were 'Krșna ke gitt'. These are, unsurprisingly, songs on the life, beauty, and themes from the mythology of Krishna. Ashk cites an example by Maulvi Maqbul Ahmad Husenpuri, originally published in the Urdu journal Humāyü $\dot{n}$, over whose poetry 'the colour of Braj Bhasha prevails', but which, had it not been published in an Urdu journal by a Muslim Urdu author, would be unlikely to be recognised as 'Urdu' at all:

\section{Rādhā-svāmī / Antaryāmī / Paramānand kī rāh sujhāo / Baṃsìdhar maharāj hamāre / Hr̆day mem̉ bamsī bajāo.46}

Lord of Radha / supreme being / show the path to ultimate bliss / Our flute-playing king / play the flute in [my] heart.

Other selections in this section are in a similar linguistic vein, as is the original gìt by Hafiz Jalandhari, which Ashk considers to have been at the forefront of this literary revolution,

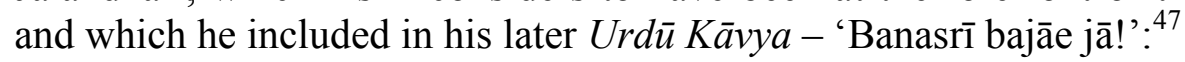

\footnotetext{
${ }^{43}$ Geeta Patel, Lyrical movements, historical hauntings: On gender, colonialism and desire in Miraji's Urdu poetry, Stanford, Stanford University Press, 2001, p. 51.

${ }^{44}$ Upendranath Ashk, Urdū kāvya kī ek naī dhārā (Allahabad: Hindustani Academy, 1949 [1941]);

Upendranath Ashk, 'Ādhunik urdū kavitā mem gìt', Hindustānī (H) 8, 2, April 1938, pp. 133-57;

8, 3, July 1938, pp. 263-84.

${ }^{45}$ See, for example, Upendranath Ashk, Urdī kī behtarīn ghazalem, Allahabad, Nilam Prakashan, 1962; Urdī kī behtarīn nazamem, Allahabad, Nilam Prakashan, 1962.

${ }^{46}$ Ashk, ‘Ādhunik', p. 136.
} 
This is the version of the article accepted for publication in Modern Asian Studies published by Cambridge University Press: https://www.cambridge.org/core/journals/modern-asian-studies/all-issues

Accepted version downloaded from SOAS Research Online for private research and study only:

http://eprints.soas.ac.uk/23095/

Bansarā bajāe jā̄!

Kāhan murlīvāle, nand ke lāle,

Bansarī bajāe jā!

Prìt mè̉ basī hū̄ adāomi se,

Gīt meì basī huī sadāomi se,

Brajbāsiyom ke jhompre basāe jā,

Sunāe jā, sunāe jā!

Kāhan murlì vale nand ke lāle,

Bansarī bajāe jā!

Bansarī kì lay nahìm haim àg hai,

Aur kō̄ śay nahìm hai àg hai,

Prem kī yah āg cār sū lagāe jā!

Sunāejā, sunāejā!

Kāhan murlì vale nand ke lāle,

Bansarī bajāe jāa!
Play the flute!
Krishna the flute player, Nand's dear son,
Play the flute!
From manners dwelling in love,
From sounds dwelling in song,
Establish the huts of the inhabitants of Braj,
Let them hear, let them hear!
Krishna the flute player, Nand's dear son,
Play the flute!
It's not the tune of the flute, but fire,
And there is nothing real, only fire,
Set the fire of love in all directions!
Let them hear, let them hear!
Krishna the flute player, Nand's dear son,
Play the flute!

Urdu git as presented by Ashk, then, were almost thematically indistinguishable from the bhakti devotional lyrics of Braj.

In the case of other themes, too, Ashk interspersed poetic quotations with brief commentary or analysis, reinforcing at every opportunity the universal appeal, in his view, of these songs, and in particular their non-communal aspects. This is evidenced not only by his balanced selection of Hindu and Muslim writers throughout, but most especially in his section on "Ektā ke gìt" (Songs of Unity). Here, having quoted part of another song by Hafiz (“Apne man mem prīt”), Ashk commented:

Pañjāb sāmpradāyiktā ke lie badnām hai aur pañjāb ke musalmān sāmpradāyiktā ke kațtar anuyāȳi kahe jāte haim. Usī pañjāb ke musalmān kavi ke mumh se sāmpradayiktā ke viruddh aisī bāt nikalnā kyā gaurav kā viṣay nahìm hai, aur kyā yah navyug kī pratinidhi hind̄̄ bhāṣā ke prabhāv kā spașt pramān nahìm haìm?

The Punjab is infamous for communalism, and Punjabi Muslims are said to be fierce adherents of communalism. Isn't it a great thing for such anti-communal sentiments to come from the mouth of a Muslim poet from that same Punjab, and isn't this clear evidence of the influence of the representative Hindi language of this new age ${ }^{48}$

This passage (which is for some reason absent from the later book, which in many parts is otherwise a verbatim copy of the original articles), sheds further light on Ashk's understanding of modern Hindi and its relationship with Urdu. Ashk saw this process of influence as unproblematic, and 'prabhā v' is the word he employed most often to characterise the relationship between Hindi and Urdu poetry as regards this new trend. However, it is not clear that such a term carried particular connotations of subordination or submission on the part of the Urdu authors; rather, it would seem that Ashk was praising these various poets for looking beyond the narrow confines of 'traditional' Urdu, in terms of both register and form, and creating a form of Urdu poetry and song that was accessible to all. ${ }^{49}$ It was for this reason that he reserved special praise for Miraji who, according to

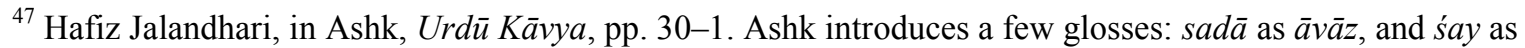
vastu. 'Bansrā' in the first line is likely a misprint.

${ }^{48}$ Ashk, 'Ādhunik', 146.

${ }^{49}$ See Daisy Rockwell, Upendranath Ashk, New Delhi, Katha, 2004, pp. 105-14, for her own rehabilitation of the term in the context of discussing Ashk's own novels.
} 
This is the version of the article accepted for publication in Modern Asian Studies published by Cambridge University Press: https://www.cambridge.org/core/journals/modern-asian-studies/all-issues

Accepted version downloaded from SOAS Research Online for private research and study only:

http://eprints.soas.ac.uk/23095/

Ashk, had fulfilled the potential of this type of writing by expanding its horizons to include free verse, and with great success. ${ }^{50}$ Fundamentally, Ashk's understanding of Hindi and Urdu was a syncretic one: he saw these new forms of poetry as existing not so much at a point on a linear Hindi-Urdu spectrum, but in a broad and (probably intentionally) illdefined arena that encompassed a broad range of registers, a malleability of form, and in which cultural influences from a variety of traditions - including Punjabi and, thanks to the efforts of Miraji among others, foreign poetry-were welcome. As an illustrative example, he quotes a poem by Maulana 'Vaqar':

Jagat mem ghar kī phūt burī!

Phüt ne raghuvar ghar se nikāle pāpan phüt

burī,

Rāvan se balvān pichāre jal gaī lañkāpurī,

Jagat mem...

Phūt paṛi to karbal jākar hue husen śahīd,

Mān ho jin kā sāre jag mei் mare unhem yazìd,

Jagat mem...

Phūt ne apnā deś bigārā kho dī sab kī lāj,

Banā huā hai deś akhārāa phūt burī mahārāj,

Jagat mem...

Tan se kaprā pet se roṭi phūt ne lì hathiyāy,

Dhan bal mān sabhī kuch apnā ham ne diyā

Jagat meṁ ghar kī phūṭ burī!
In the world, a rift in the house is bad!

A rift forced Rama from

his house - bad sinful rift,

He defeated one as strong as Ravana, Lanka

burned,

In the world...

A rift occurred and Hussain went to Karbala and was martyred,

He who was honoured by the world was killed by Yazid,

In the world...

A rift ruined our country, laid waste to our honour, The country has been made into a wrestling ground by this bad rift, sir,

In the world...

This rift has snatched clothes from the back and food from the stomach.

We have squandered our wealth, strength gamivay and pride...

In the world, a rift in the house is bad! ${ }^{11}$

The attractions this piece must have had to Ashk and his project are obvious. Vaqar created a nominally Urdu poem with a complete lack of what might be considered 'excessively' Persian- or Arabic-derived vocabulary. Moreover, in his warning against the debilitating effects of disunity he highlighted the dangers of rifts or schisms not merely in contemporary society, but by drawing on two foundational tales from Hindu and (at least Shi'a) Muslim community narratives. The point seems to be that a poetry of unity has the space for both. In Ashk's presentation of the poem, more emphatically, this was a form of poetry that defied easy or exclusive linguistic classification. This is not to say that all such practices that pointed towards a transcending of the linguistic or literary divide necessarily implied a desire to cross religious or communal divides - not even all of the examples included here. Nevertheless, in the face of powerful drives to create 'pure' Hindi and Urdu, and to separate out distinct literary canons and traditions and tastes, moments of nonconformity retain a special significance.

Such contrariness represented, in some cases, the endurance of a rich and diverse literary habitus, which persisted against the ultimately limited normative potential of the rupturing influences of these same nationalisms. In other cases, journals and publications

\footnotetext{
${ }^{50}$ Ashk, Urdū Kāvya, 130.

${ }^{51}$ Maulana Vaqar, 'Jagat mem', in Ashk, Urdū kāvya, pp. 36-7.
} 
This is the version of the article accepted for publication in Modern Asian Studies published by Cambridge University Press: https://www.cambridge.org/core/journals/modern-asian-studies/all-issues

Accepted version downloaded from SOAS Research Online for private research and study only:

http://eprints.soas.ac.uk/23095/

acted as the means by which poets and poetry from the 'other' tradition were (re)introduced to readers, and the consumption of śers became a part of Hindi reading practices, for example. In yet others, it took the form of creative experiments with language, by which efforts a new habitus was formed that itself laid the groundwork for an enduring set of tastes that would withstand the ravages of independence and Partition. As Krishnadevprasad Gaur observed approvingly, it was indeed possible to create poetry of depth and meaning in a register that was accessible and free of the artificial, imported 'excesses' of Persian, Arabic or Sanskrit vocabulary or conventions: a poetry which, even on close inspection, was almost impossible to classify as either 'Hindi' or 'Urdu'. ${ }^{52}$ A focus on these crossover figures, who themselves both searched for and helped to create the 'common ground' that is the focus of this article, in no way denies the reality of the quite frankly undeniable effect that linguistic and literary divisions ultimately had. It aims instead to broaden our understanding of the Hindi-Urdu field of cultural production, and to bring us a step closer to appreciating the nuances and slippages between these apparently separate fields that existed in the early decades of the twentieth century.

\section{Some Conclusions}

I prefer never to ask or answer the question 'what is Hindustani?'-it can be as cyclical today as it was in the decades leading up to Independence. Thankfully, that isn't the question here: rather, I have been far more interested in what Hindustani meant to the writers and institutional actors of the period, and what were some of the practical-literary, imaginative, associational - outworkings of these meanings. The modern history of Hindi and Urdu as literatures and languages, and their association with discrete religious communities, has of course not been as straightforward or linear as studies might have suggested, and the spaces that existed, were (re-)created, and endured between the poles deserve our attention. Hindustani as a concept may-then as now-remain a fuzzy one, though that in itself does not denude it of utility; moreover, in adopting what I have described as a policy of 'strategic ambiguity', it seems clear that at least one group of writers were endeavouring to fashion Hindustani as a progressive space of potential, in opposition to less flattering, and divisive, understandings of the term. In the projects of the Hindustani Academy, in the writings of Ashk, and in many other attempts to bridge the divide, it stood for a cultural and linguistic space of commonality and tolerance, wherein language might be delinked from the pernicious aspects of nationalism and religious communalism, and function instead as a site of communication, mutuality, and creativityor, as a common ground.

\footnotetext{
52 'Kahīm kahīm to ais̄̄ kavitāem hone lagī haìm ki āp kah nahīm sakte ki yah urdū kī kavitā hai ki hindī kī. Hamārā yah kahnā nahīì ki bhāṣā ke lie bhāv kī hatyā kī jāy; par ham yah bhī nahīm cāhte ki kavitā kī chāyā mem śabdom kā ạdambar racā jāy.' ('In some places a kind of poetry has begun that is impossible to say whether it is Urdu or Hindi. I am not saying that affect should be murdered for the sake of language; but I also don't want that the pretension of words should flourish under the cover of poetry.') Krishnadevprasad Gaur, 'Hindī kavitā kī bhāṣā', in Haṃs 6, 2, November 1935, pp. 66-8, p. 67.
} 